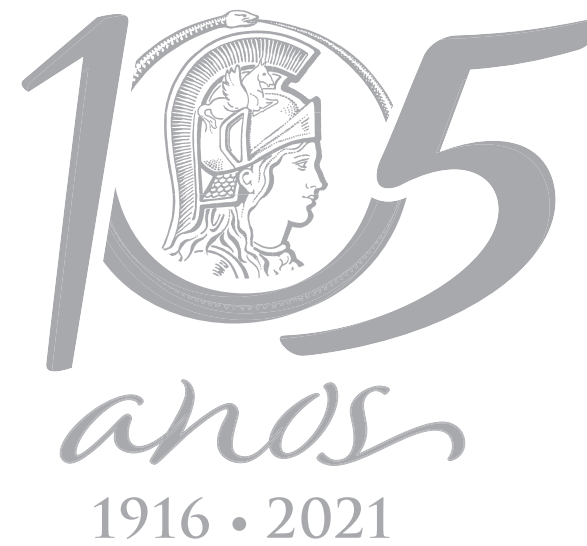

$1916 \cdot 2021$

\title{
Inclusion of industrial egg residue in the feed of laying hens to replace limestone: digestibility, productive performance and egg quality
}

\author{
MAURICIO BARRETA, MARCEL M. BOIAGO, ALINE ZAMPAR, BRUNO F. FORTUOSO, \\ ROGER R. GEBERT, EDUARDO ROSCAMP, ROSILENE C. OLIVEIRA, JÉSSICA D. \\ DALIANE, MARINDIA KOLM, GABRIELA M. GALLI \& ALEKSANDRO S. DA SILVA
}

\begin{abstract}
Our objective was to determine whether inclusion of industrial egg residue (IER) in the diets of laying hens would replace calcitic limestone without interfering with productive efficiency, egg quality or digestibility. In a first study (Experiment I), we used $30 \%$ IER in the diets of laying hens and found that the apparent digestibility coefficients were $51.6 \%, 42.8 \%, 51.6 \%$ and $17.8 \%$ for dry matter, crude protein, calcium and phosphorus, respectively. In the second study (Experiment II), we compared a control diet containing calcitic limestone with four diets containing increasing levels of IER, in proportions of $25 \%, 50 \%, 75 \%$ and $100 \%$. During the first cycle (day $1-28$ ), there was no difference between treatments in terms of productive performance or egg quality. During the second production cycle (day 29-56), we observed less food consumption by birds that ingested the highest levels of IER (100\% substitution) than in controls. During the third cycle (day 57-84), we found that the inclusion of IER negatively affected performance, particularly lower production numbers, lower egg mass and higher feed conversion. Finally, during the third cycle, chickens broke and ingested their eggs shortly after laying. We conclude that the use of industrial egg residue cannot replace limestone in the feed of commercial laying hens, because it reduces performance and affects egg quality.
\end{abstract}

Key words: Animal behavior, calcium, eating, phosphorus.

\section{INTRODUCTION}

Industrial egg production is becoming increasingly common worldwide. These processes generate large volumes of waste, most of which is currently used as organic fertilizer or is discarded in landfills. This material consists primarily of shells and residual albumen. The shell is composed primarily of calcium carbonate (Murakami et al. 2007) and the albumen remnants, matrix and shell film contribute to the protein and energetic composition of the residue. Its bromatological composition makes animal waste useful for feed formulations (Garcia 2010), possibly contributing to the sustainability of production systems as well as lowering production costs; according to Marinho et al. (2010), these costs can reach 70\% of the total.

Alternative sources of calcium have been explored; nevertheless, industrial egg residue (IER) has not yet been tested in commercial laying hens in terms of its composition, digestibility or effects on production. Lima (2016) tested eggshell flour as an alternative source of calcium and found a bromatological composition distinct from that of the residue. Our research group conducted a pilot study with 
IER in Japanese quail feed and found that the substitution did not affect variables related to egg production or quality (unpublished data); nevertheless, we measured only metabolizable energy and did not evaluate IER nutrient retention. Therefore, in the present study, we determined whether replacement of limestone by IER at various levels would interfere with production, quality and efficiency of egg laying in hens; we also measured various effects on digestibility indexes.

\section{MATERIALS AND METHODS}

\section{Experimental location and ethical approval}

The experiment was carried out in an experimental poultry house in southern Brazil. The study took place in during the Brazilian winter, where temperatures ranged between 1.2 o C and 29 oC, with humidity ranging from $62 \%$ to $95 \%$. The project was approved by the committee of animal use in the research of the State University of Santa Catarina, protocol number 5326030418.

\section{Industrial egg residue (IER)}

The IER was obtained from an industrial egg pasteurization plant located in the municipality of Chapecó, SC and was processed (dehydrated and ground) in the animal nutrition laboratory of UDESC. The residue was dehydrated in a forcedair chamber at 55 oc until constant weight was obtained. Subsequently, it was ground in a hammer mill with 1-mm pores. To measure the contents of dry matter, mineral matter, crude protein, ethereal extract, calcium and phosphorus, we used methodologies described by Silva \& Queiroz (2006). Crude energy was measured using a calorimetric pump (Model IKA (200 ${ }^{\circledR}$ ).

Total bacterial counts (TBC), total coliforms (TC), Salmonella spp. and Escherichia coli were measured in fresh eggshells and IER. The total bacterial counts were performed according to the Normative Instruction (Number 62 of 26 August 2003) from the Ministry of Agriculture, Livestock and Supply (Brazil). Quantifications of Salmonella, E. coli and total coliforms were made using 3M TM Petrifilm Plates. The numbers of colony forming unit (CFU) were evaluated after $48 \mathrm{~h}$ incubation of samples at controlled temperature.

In the microbiological analysis of fresh (without processing) eggshells, we found $8.4 \mathrm{x}$ $10^{5} \mathrm{CFU} / \mathrm{g}, 5.4 \times 10^{4} \mathrm{CFU} / \mathrm{g}$ and $2.1 \times 10^{4} \mathrm{CFU} / \mathrm{g}$ of TBC, TC and E. coli, respectively. In the IER, TC and E. coli were not found; however, the TBC count was $4.6 \times 10^{2} \mathrm{CFU} / \mathrm{g}$. Salmonella spp. were not identified in any samples.

\section{Experiment I: digestibility assay}

\section{Animals, experimental design and sample collection}

For the digestibility assay, we used $30 \mathrm{Hy}$-Line Brown hens in laying phase at 28 weeks. The hens were housed in metabolic cages (3 hens/ cage) made of galvanized steel fitted with trough-type feeders and nipple drinkers. The birds were allocated into groups receiving one of two diets (reference and control), with five replicates for each group.

The experimental diets consisted of a reference diet (Table I), based on corn and soybean meal, formulated according to chemical composition and energy values proposed by Rostagno et al. (2017) and a test diet, composed of $70 \%$ of the reference diet and $30 \%$ of IER (Sakomura \& Rostagno 2007).

The experiment lasted eight days: four days for adaptation to experimental diets and four days for total excreta collection, following a model by Matterson et al. (1965). After the 
Table I. Ingredients and calculated chemical composition of the diet base and reference to be used in the Experiment I of digestibility, following recommendations of the Brazilian table of poultry nutrition (Rostagno et al. 2017).

\begin{tabular}{|c|c|}
\hline Ingredients & $\%$ \\
\hline Corn & 65.7 \\
\hline Soybean meal (45\%) & 21.8 \\
\hline Calcitic limestone & 8.90 \\
\hline Soybean oil & 1.10 \\
\hline Dicalcium phosphate & 1.50 \\
\hline DL-Methionine (98\%) & 0.20 \\
\hline Sodium chloride ( $\mathrm{NaCl}$ ) & 0.50 \\
\hline Vit. and mineral premix* & 0.30 \\
\hline TOTAL & 100.00 \\
\hline \multicolumn{2}{|c|}{ Calculated centesimal composition } \\
\hline Metabolizable energy (Kcal/Kg) & 2.84 \\
\hline Crude protein (\%) & 15.6 \\
\hline Calcium (\%) & 3.87 \\
\hline Available phosphorus (\%) & 0.37 \\
\hline Digestible lysine (\%) & 0.68 \\
\hline Digestible methionine (\%) & 0.42 \\
\hline Methionine + dig. cysteine (\%) & 0.65 \\
\hline Sodium & 0.23 \\
\hline
\end{tabular}

* Product composition (kg): vit. A 7,000,000 IU; vit. D3 4,000,000 IU; vit. E 5000 mg; vit. K 1200 mg; vit. B1 360 mg; vit. B2 2000 mg; vit. B6 700 mg; vit. B12 7000 mcg; niacin 7500 mg; biotin $30 \mathrm{mg}$; pantothenic acid $6000 \mathrm{mg}$; folic acid $300 \mathrm{mg}$; choline 200 mg; iron 11000 mg; copper 3000 mg; iodide 204 $\mathrm{mg}$; chloride $360 \mathrm{mg}$; growth promotion efficiency. Feed 20 mg; coccidiostatics 100 g; antifungals 2000 mg; antioxidants $10 \mathrm{mg}$; magnesium 50 g; sulfur 40 g; energy and protein vehicle (q.s.p.) 1,000 g.

adaptation period, the excreta were collected, using ferric oxide (2\%) in the diet as a marker of the beginning and end of the collection. During the entire experimental period, excreta collection occupied an interval of twelve hours. The excreta were packaged, identified and frozen until the end of collection.

\section{Analysis of samples and data}

Subsequently, the excreta were thawed, homogenized, weighed and dried in a forced-air chamber at 55 oC for 72 hours. After drying, the samples were ground to determine dry matter (DM), mineral matter (MM), crude energy (CE), crude protein (CP), calcium (Ca) and phosphorus $(P)$. We calculated the following parameters: apparent metabolizable energy (MEa); coefficient of apparent dry matter digestibility (CDMDa), coefficient of apparent crude protein digestibility (CCPDa); coefficient of apparent mineral matter digestibility (CMMDa); coefficient of apparent calcium digestibility (CACaD); and coefficient of apparent phosphorus digestibility (CPDa). Calculation of MEa followed the model recommended by Sakomura \& Rostagno (2007), using the following formulae:

MEa Reference feed $=$ (ME ing reference feed - CE exc)/ DM ing;

MEa Test feed $=($ CE ing - CE exc $) / D M$ ing;

MEa food $=$ MEa ref $+($ MEa test - MEa ref $) / g$ of ingredients per $g$ of feed.

where $\mathrm{MEa}=$ apparent metabolizable energy; CE ing = Crude energy intake; CE exc. = Crude energy excreted; DM ing = Dry matter ingested; MEa ref = apparent metabolizable energy of reference feed; MEa test = apparent metabolizable energy of test feed.

For the determination of the apparent digestibility coefficients of the other nutrients, the model recommended by Costa (2009) was used, according to the following formulae:

$$
\mathrm{CDCP} \text { basal feed }=(C P \text { ing }-\mathrm{CP} \text { exc }) / C P \text { ing. }
$$

$\mathrm{CDCP}_{\text {ingredient }}=\mathrm{CDCP}{ }_{\text {basal feed }}+\left(\mathrm{CDCP}_{\text {test feed }}-\right.$ $\left.\mathrm{CDCP}_{\text {basal feed }}\right) / \%$ ing.

where $C D C P=$ coefficient of digestibility of crude protein; $\mathrm{CP}$ ing. = crude protein ingested; $\mathrm{CP}$ exc. = excreted crude protein; \% ing. = Percentage of ingredient inclusion. 
Note that the other nutrients were calculated following the same methodology and the \%-inclusion values of the ingredients were calculated considering the actual proportions of inclusion.

\section{Experiment II: productive performance and egg quality}

\section{Animals and experimental design}

To perform egg quality and performance tests, we used 125 36-week-old commercial hens of the Hy-Line Brown lineage, receiving 16 light hours per day, allocated in metallic cages equipped with individual trough-type feeders and nipples drinkers.

The hens were distributed in a completely randomized design with five treatments and five replicates (cages with five hens each). The treatments consisted of increasing levels of calcium $(0,25,50,75$ and $100 \%)$ to replace limestone, based on the nutritional requirements for calcium. The IER was milled to an average particle size of $1.50 \mathrm{~mm}$, and when the inclusion of IER in the diets began, it replaced fine limestone. The experimental diets (Table II) were formulated based on corn and soybean meal and the nutritional requirements and nutritional composition of the foods were based on Brazilian tables for poultry and swine (Rostagno et al. 2017).

The experiment lasted 84 days, divided into three cycles of 28 days each, during which time hens consumed the same experimental diet. Egg collection was performed daily at noon, where the amounts in each experimental plot were recorded. At the beginning and end of each cycle, the feed was weighed so as to calculate the consumption per plot and other performance variables.

\section{Zootechnical design}

The performance variables evaluated were egg production (\%), feed intake (g/bird/day), feed conversion ( $\mathrm{kg}$ feed/ $\mathrm{kg}$ of eggs and $\mathrm{kg}$ of feed/ dozen), egg weight (g) and egg mass (g/bird/ day). To obtain the mass of eggs, in the final 3 days of each experimental cycle, all eggs of each repetition were weighed, and the average was multiplied by the percentage of production of the respective repetition.

\section{Levels of blood calcium}

Blood calcium levels were measured at the beginning of the experiment (day 0 ) and at the end of each experimental cycle (days 28, 56 and 84). Blood was collected from one bird per cage using an insulin syringe. Blood was stored in microtubes without anticoagulant, and centrifuged at $5500 \mathrm{~g}$ for $10 \mathrm{~min}$ to obtain the serum that was frozen (-20 oc) until analysis. Calcium levels were measured using a specific commercial kit (ANALISA ${ }^{\oplus}$ ) and read on semi-automatic equipment (BIOPLUS $2000^{\circledR}$ ), following the manufacturer's recommendations.

\section{Egg quality}

Egg quality was evaluated on the final of each experimental cycle (Days 28, 56 and 84). Two eggs were collected per experimental unit (cage), totaling 10 eggs per treatment, to perform analyses as follows: specific gravity (Freitas et al. 2004), and shell resistance (kgf) using a texturometer (TA.XT Plus ${ }^{\circledR}$ ) coupled to a probe P75. Haugh units (Haugh 1937), yolk index, yolk color (measured using a DSM YolkFan ${ }^{\mathrm{TM}}$ ), brightness ( $\mathrm{L}$ ), intensity of red $\left(\mathrm{a}^{*}\right)$ and intensity of yellow $\left(b^{*}\right)$ were measured using a Minolta colorimeter $\left(\mathrm{CR}-400^{\circ}\right)$; percentage of yolk, albumen and shell, thickness of the shell, $\mathrm{pH}$ of yolk and albumen were measured using 
Table II. Ingredients, diet cost and chemical composition calculated from each experimental diet used in this study with different levels of replacement of industrial egg residue with calcic limestone: Experiment II.

\begin{tabular}{|c|c|c|c|c|c|}
\hline Ingredient (\%) & TO & T25 & T50 & T75 & T100 \\
\hline Corn $(7.88 \%)$ & 65.84 & 65.72 & 65.55 & 65.40 & 65.25 \\
\hline Soybean meal (44 \%) & 20.62 & 20.04 & 19.46 & 18.88 & 18.53 \\
\hline Industrial egg residue ${ }^{1}$ & 0.00 & 3.14 & 6.28 & 9.42 & 11.38 \\
\hline Calcitic Limestone & 9.36 & 6.76 & 4.18 & 1.60 & 0.00 \\
\hline Soybean oil & 1.68 & 1.80 & 1.94 & 2.06 & 2.16 \\
\hline Dicalcium phosphate & 1.26 & 1.26 & 1.27 & 1.28 & 1.28 \\
\hline Sodium chloride ( $\mathrm{NaCl}$ ) & 0.43 & 0.43 & 0.43 & 0.43 & 0.43 \\
\hline DL-Methionine & 0.30 & 0.31 & 0.32 & 0.33 & 0.33 \\
\hline L-Lysine & 0.13 & 0.15 & 0.16 & 0.18 & 0.20 \\
\hline L-Threonine & 0.07 & 0.08 & 0.09 & 0.10 & 0.11 \\
\hline L-Tryptophan & 0.01 & 0.01 & 0.02 & 0.02 & 0.03 \\
\hline Vit. and mineral premix ${ }^{2}$ & 0.30 & 0.30 & 0.30 & 0.30 & 0.30 \\
\hline Total & 100 & 100 & 100 & 100 & 100 \\
\hline Price R\$ / kg & 1.07 & 1.06 & 1.05 & 1.04 & 1.03 \\
\hline \multicolumn{6}{|c|}{ Calculated chemical composition } \\
\hline $\mathrm{CP}(\%)$ & 14.74 & 14.74 & 14.74 & 14.74 & 14.74 \\
\hline ME (kcal/kg) & 2850 & 2850 & 2850 & 2850 & 2850 \\
\hline $\mathrm{Ca}(\%)$ & 3.90 & 3.90 & 3.90 & 3.90 & 3.90 \\
\hline Linoleic acid (\%) & 2.28 & 2.28 & 2.28 & 2.28 & 2.28 \\
\hline Available phosphorus (\%) & 0.32 & 0.32 & 0.32 & 0.32 & 0.32 \\
\hline Digestible lysine (\%) & 0.74 & 0.74 & 0.74 & 0.74 & 0.74 \\
\hline Digestible methionine (\%) & 0.52 & 0.52 & 0.52 & 0.52 & 0.52 \\
\hline Digestible Met.+ Cyst. (\%) & 0.72 & 0.72 & 0.72 & 0.72 & 0.72 \\
\hline Digestible threonine (\%) & 0.57 & 0.57 & 0.57 & 0.57 & 0.57 \\
\hline Digestible tryptophan (\%) & 0.17 & 0.17 & 0.17 & 0.17 & 0.17 \\
\hline Sodium (\%) & 0.18 & 0.18 & 0.18 & 0.18 & 0.18 \\
\hline Chloride (\%) & 0.32 & 0.32 & 0.32 & 0.32 & 0.32 \\
\hline
\end{tabular}

Note: ${ }^{1}$ residue industrial egg production, including: $98.4 \%$ dry matter, $7.5 \%$ crude protein, $31 \%$ calcium, $0.16 \%$ phosphorus, $1.85 \%$ of ethereal extract and the crude energy was $635 \mathrm{Kcal} / \mathrm{kg}$.

${ }^{2}$ Premix composition: folic acid (200 mg/ kg); pantothenic acid (min $4.33 \mathrm{mg} / \mathrm{kg}$ ); copper (min $\left.2.66 \mathrm{mg} / \mathrm{kg}\right)$; choline (min $78.12 \mathrm{mg} /$ $\mathrm{kg}$ ); iron (min $16.7 \mathrm{mg} / \mathrm{kg}) ;$ phytase (min $166.66 \mathrm{ftu} / \mathrm{kg}) ;$ iodide (min $400 \mathrm{mg} / \mathrm{kg}$ ); manganese (min $23.3 \mathrm{~g} / \mathrm{kg}) ; \operatorname{niacin}(\mathrm{min} 10 \mathrm{~g} /$ $\mathrm{kg}$ ); selenium (min $66.7 \mathrm{mg} / \mathrm{kg}$ ); vitamin A (min 2,333,333 IU/ kg); vitamin B1 (min $666.7 \mathrm{mg} / \mathrm{kg}) ;$ vitamin B12 (min $3.333 \mathrm{mcg} / \mathrm{kg})$; vitamin B2 (min $1.666 \mathrm{mg} / \mathrm{kg})$; vitamin B6 (min $1000 \mathrm{mg} / \mathrm{kg})$; vitamin D3 (min $733.333 \mathrm{lU} / \mathrm{kg}) ;$ vitamin E (min 3,666 IU / kg); vitamin K3 (min $533.33 \mathrm{mg} / \mathrm{kg})$; zinc (min $16.7 \mathrm{~g} / \mathrm{kg})$; colistin sulfate $(\min 3.333 \mathrm{mg} / \mathrm{kg})$.

digital pH meter (Testo $205^{\circ}$ ) and mean egg weight. To calculate the shell percentage and shell thickness, eggs were broken and washed to remove excess albumen and dried in forced air for 24 hours at $55^{\circ} \mathrm{C}$. After drying, the shells were weighed and the thickness was measured in the basal and equatorial portions using a digital pachymeter to later obtain the average of the two measurements.

\section{Statistical analysis}

A completely randomized design with five treatments and five replicates each was used. 
The treatments consisted of the increasing substitution of the calcitic limestone by IER at $0,25,50,75$, and $100 \%$. The obtained data were subjected to analysis of normality of distribution and then analysis of variance. In cases of significant differences, the means were subjected to polynomial regression and compared using the Tukey test (5\%). For blood calcium concentrations, we used a design of measures repeated over time and Tukey test.

\section{RESULTS AND DISCUSSION}

The bromatological composition of IER stands is characterized by its levels of calcium, crude protein and ethereal extract (Data in the footer of Table II). When analyzing the calcium levels, we observed that the residue contained approximately $82 \%$ of the level of calcium found in calcitic limestone, the main source of calcium used in animal nutrition. However, IER presented a considerable concentration of crude protein that does not exist in limestone. The results obtained for crude protein and ethereal extract are explained by the fact that the residue has a certain quantity of albumen and yolk, structures rich in proteins and fats, respectively.

The metabolizability of crude energy was $33 \%$, generating apparent metabolizable energy of $209.95 \mathrm{kcal}$ (Table III). This low efficiency is explained by the low digestibility of dry matter and crude protein, probably because of the high mineral concentration in the product. Products with lower concentrations of mineral matter such as meat-and-bone meal (48\%) and soybean meal have, according to Rostagno et al. (2017) crude protein digestibility of $80.4 \%$ and $91 \%$, respectively. The coefficient of digestibility of calcium was lower than that of calcitic limestone. Sá et al. (2004) and Leão (2018) found values of $84.67 \%$ and $81.57 \%$ for
Table III. Coefficient of apparent dry matter digestibility (CDMDa), coefficient of apparent digestibility of crude protein (CDCPa), coefficient of apparent digestibility of calcium (CDCa), coefficient of apparent phosphorus digestibility (CPDa) and apparent metabolizable energy (MEa).

\begin{tabular}{|c|c|}
\hline Variable & $\%$ \\
\hline CDMDa & 51.66 \\
\hline CDCPa & 42.81 \\
\hline CDCa & 51.66 \\
\hline CPDa & 17.81 \\
\hline $\mathrm{MEa}(\mathrm{Kcal} / \mathrm{Kg})$ & 209.95 \\
\hline
\end{tabular}

calcitic limestone, respectively. Low phosphorus retention was observed, due to the fact that the nutrient is present at low levels in the feed.

Table IV shows that the treatments did not substantially influence the amount of calcium in the blood of the hens, except when comparing the control treatment (TO) with T75, because TO presented a significantly smaller amount of calcium. We observed that serum calcium levels significantly decreased with advancing age of hens. According to Vieira (2009), for the absorption of this mineral to take place, calcium binding proteins are required, and these show diminished activity with the passage of time (Costa et al. 2010).

No significant differences were observed in terms of performance results (Table 5) or in the qualitative aspects of the eggs (Table VI) during the first and second production cycles, suggesting that total replacement of limestone by IER did not affect the hens. Nevertheless, in the second cycle for the feed consumption variable, there was a linear decrease as the inclusion of the residue increased (Figure 1). This behavior was also observed by Reis et al. (2012), when evaluating the total and partial replacement of calcitic limestone in Japanese quail diets; that is, there was a linear and numerical reduction 
Table IV. Blood calcium levels $(\mathrm{mg} / \mathrm{dL}$ ) of the hens submitted to the treatments at the different collection periods, that is, at the beginning of the experiment (day 0 ) and at the end of each production cycle (days 28, 56 and 84).

\begin{tabular}{|c|c|}
\hline & Treatment (T) \\
\hline T0 & $28.20 \mathrm{~B}$ \\
\hline T25 & $33.24 \mathrm{AB}$ \\
\hline T50 & $30.73 \mathrm{AB}$ \\
\hline T75 & $34.39 \mathrm{~A}$ \\
\hline T100 & $31.20 \mathrm{AB}$ \\
\hline P-value & 0.043 \\
\hline Days of collection (DC) \\
\hline 0 & $44.44 \mathrm{~A}$ \\
\hline 28 & $33.04 \mathrm{~B}$ \\
\hline 56 & $25.13 \mathrm{C}$ \\
\hline 84 & $23.59 \mathrm{C}$ \\
\hline P- value for Tx DC & 0.118 \\
\hline P-value for collection & $<0.001$ \\
\hline CV (\%) & 16.51 \\
\hline
\end{tabular}

A, B Different letters in the same column indicate significant difference by the Tukey test $(\mathrm{P}<0.05)$. CV = coefficient of variation.

in feed consumption by the hens. Because IER was included in the diet there was a withdrawal of thick calcitic limestone, and this difference in granulometry may have interfered by increasing the amount of soluble calcium. In these cases, there is rapid absorption in the intestine (Bronner 1998), and consequent elevation of ionic calcium in the blood, inhibiting the hen's appetites (Lobaugh et al. 1981).

In the third production cycle, we observed significant effects of experimental diets on a larger number of variables, both productive (Table V) and qualitative variables (Table VI). Figure 2 shows that, as the limestone was replaced by the IER, the productive indexes became lower, except for feed consumption. In this cycle, there was a decrease in egg production (Table $V$ ), occurring as a possible result of nutrient deficiency during the experimental period (mainly crude protein) because as IER was added, the amount of soybean meal decreased linearly. Another observation suggesting nutritional deficiency was consumption of eggs by hens, because this behavior occurred in all experimental treatments that included IER in feed composition.

In the first productive cycle, there were no alterations in egg quality variables; in the second cycle, two variables differed (Table VI); that is, we observed significant differences in the indices of coloration ( $\mathrm{L}$ and range) and for $\mathrm{pH}$ of the albumen. For coloration evaluated using the colorimetric range $(\mathrm{L})$ we obtained a quadratic equation $\left(Y=6.05+0.0389 X-0.000222 X^{2}, R^{2}=\right.$ $0.51)$. For the value of $L$, we observed linear behavior $\left(Y=58.11+0.0218 X, R^{2}=0.15\right)$, suggesting that the increase in dietary IER caused egg yolk to become brighter. Nevertheless, the aspect that showed the greatest relationship with the experimental diets was the $\mathrm{pH}$ of the albumen, showing a positive linear regression $(Y=8.19+$ $\left.0.00256 X, R^{2}=0.28\right)$; that is, as the amount of IER in the diet increased, the $\mathrm{pH}$ of the albumen became higher. This observation may be explained by the inverse relationship of food intake and $\mathrm{pH}$ of the albumen, because, when eating less food, the bird ingests lower amounts of crude protein, causing lower deposition of amino acids in the albumen and consequent alkalization of egg pH. Cupertino et al. (2009) reported that hens ingesting lower levels of methionine and cystine presented both lower egg production and lower egg weight than those receiving adequate doses of these amino acids.

In the third production cycle, three other egg quality variables differed between treatments (Table VI); that is, the colorimetric range that increased with elevation of substitution levels, as well as shell percentage and shell thickness that decreased with higher IER levels. The linear reduction in both shell thickness and percentage 
Table V. Production percentage averages (PP), feed intake (Fl, g/hen/day), egg mass (EM, g/hen/day) and feed conversion $(\mathrm{FC}, \mathrm{Kg} / \mathrm{dz}$ and $\mathrm{kg} / \mathrm{kg}$ ) of the hens that received the different levels of industrial egg residue in the diet to replace calcitic limestone in the first, second and third production cycles.

\begin{tabular}{|c|c|c|c|c|c|}
\hline Treatment & PP & $\mathbf{F I}$ & EM & FC (Kg/dz) & FC (Kg/Kg) \\
\hline \multicolumn{6}{|c|}{ First cycle of production } \\
\hline T0 & 91.42 & 113.96 & 57.65 & 1.61 & 1.92 \\
\hline $\mathrm{T} 25$ & 90.71 & 112.21 & 58.66 & 1.67 & 1.91 \\
\hline $\mathrm{T} 50$ & 92.14 & 109.06 & 54.61 & 1.67 & 2.08 \\
\hline $\mathrm{T} 75$ & 92.71 & 110.04 & 60.44 & 1.57 & 1.82 \\
\hline $\mathrm{T} 100$ & 88.75 & 107.78 & 57.02 & 1.58 & 1.92 \\
\hline $\mathrm{P}$ & 0.44 & 0.28 & 0.152 & 0.48 & 0.19 \\
\hline $\mathrm{CV}(\%)$ & 3.80 & 4.24 & 6.41 & 6.84 & 8.26 \\
\hline \multicolumn{6}{|c|}{ Second cycle of production } \\
\hline TO & 93.39 & $131.75 \mathrm{~A}$ & 59.44 & 1.66 & 2.17 \\
\hline $\mathrm{T} 25$ & 91.85 & $127.06 \mathrm{AB}$ & 58.87 & 1.68 & 2.08 \\
\hline $\mathrm{T} 50$ & 88.92 & $125.86 \mathrm{AB}$ & 56.47 & 1.67 & 2.23 \\
\hline $\mathrm{T} 75$ & 93.03 & $124.77 \mathrm{AB}$ & 61.06 & 1.58 & 2.04 \\
\hline $\mathrm{T} 100$ & 87.28 & $119.42 \mathrm{~B}$ & 56.00 & 1.64 & 2.14 \\
\hline$P$ & 0.388 & $0.026^{*}$ & 0.16 & 0.793 & 0.13 \\
\hline CV & 5.86 & 5.39 & 6.89 & 6.54 & 7.01 \\
\hline \multicolumn{6}{|c|}{ Third cycle of production } \\
\hline T0 & $90.41 \mathrm{~A}$ & $136.16 \mathrm{AB}$ & $58.60 \mathrm{~A}$ & $1.73 \mathrm{~B}$ & $2.45 \mathrm{AB}$ \\
\hline $\mathrm{T} 25$ & $87.50 \mathrm{AB}$ & $144.34 \mathrm{~A}$ & $58.27 \mathrm{~A}$ & $1.99 \mathrm{~A}$ & $2.32 \mathrm{~B}$ \\
\hline $\mathrm{T} 50$ & $77.50 \mathrm{BC}$ & $132.30 \mathrm{AB}$ & 50.95 B & $2.13 \mathrm{~A}$ & $2.62 \mathrm{~A}$ \\
\hline $\mathrm{T} 75$ & 76.66 C & $135.28 \mathrm{AB}$ & $52.54 \mathrm{~B}$ & $1.94 \mathrm{AB}$ & $2.66 \mathrm{~A}$ \\
\hline $\mathrm{T} 100$ & $72.16 \mathrm{C}$ & $128.53 B$ & 46.65 B & $2.11 \mathrm{~A}$ & $2.67 \mathrm{~A}$ \\
\hline $\mathrm{P}$ & $<0.001^{*}$ & $<0.001^{*}$ & $<0.001^{*}$ & $<0.001^{*}$ & $0.017^{\star}$ \\
\hline CV & 6.82 & 6.41 & 6.55 & 6.37 & 6.69 \\
\hline
\end{tabular}

Note: $\mathrm{CV}=$ Coefficient of variation; ${ }^{*} \mathrm{P}<0.05$ indicates the difference between treatments, the differences being shown by equal letters on the same line (Tukey test).

may be directly related to blood calcium levels in the third production cycle; this is because older hens tended to have lower intestinal calcium absorption capacity, attributable to a reduction in activity of calcium transporter proteins (Costa et al. 2010).

Intake of IER for long-term commercial laying hens is not recommended; however, it may be used occasionally for short periods. This is because over the long term (i.e., $3^{\text {rd }}$ cycle) the birds engaged in egg ingestion behavior shortly after oviposition; there was also a combined nutritional deficiency of low IER digestibility and a significantly reduced laying rate. Further studies with the cost-effectiveness of this byproduct are needed to confirm these results, as well as to associate with other ingredients, which may have other positive effects on laying birds. We believe that laying hens consumed eggs because of calcium deficiency; nevertheless, this hypothesis should also be investigated. 
Table VI. Egg quality: Haugh units (HU), Yolk index (YI), yolk coloring using the colorimetric DSM range (range), luminosity (L), yellow intensity $\left(a^{*}\right)$, yellow intensity $\left(b^{*}\right)$, yolk percentage (YP), Shell percentage (SP), albumen percentage (PA), shell thickness (ST, mm), yolk pH (Y pH), albumen pH (A pH), specific gravity (SG) and shell resistance (SR, Kgf) of eggs from the first, second and third production cycles.

\begin{tabular}{|c|c|c|c|c|c|c|c|}
\hline \multirow{2}{*}{ Variable } & \multicolumn{5}{|c|}{ Treatment } & \multirow{2}{*}{$\mathbf{P}$} & \multirow{2}{*}{ CV (\%) } \\
\hline & TO & T25 & T50 & T75 & T100 & & \\
\hline \multicolumn{8}{|c|}{10 cycle of production } \\
\hline $\mathrm{HU}$ & 92.19 & 93.11 & 89.34 & 92.38 & 91.64 & 0.203 & 2.69 \\
\hline $\mathrm{YI}$ & 0.49 & 0.5 & 0.47 & 0.51 & 0.53 & 0.086 & 6.26 \\
\hline Range & 5.40 & 5.20 & 5.10 & 5.00 & 4.70 & 0.129 & 7.87 \\
\hline L & 62.30 & 60.02 & 61.23 & 60.38 & 61.58 & 0.328 & 3.00 \\
\hline$a^{*}$ & -6.80 & -6.15 & -6.63 & -7.08 & -6.61 & 0.122 & 7.79 \\
\hline$b^{*}$ & 48.22 & 46.86 & 49.11 & 46.34 & 47.54 & 0.534 & 5.63 \\
\hline YP & 26.42 & 25.87 & 26.02 & 25.81 & 25.85 & 0.902 & 4.26 \\
\hline SP & 9.84 & 9.49 & 9.35 & 9.58 & 10.05 & 0.230 & 5.18 \\
\hline PA & 63.57 & 64.72 & 64.66 & 64.61 & 64.5 & 0.742 & 2.36 \\
\hline ST & 0.36 & 0.35 & 0.35 & 0.36 & 0.37 & 0.077 & 4.44 \\
\hline $\mathrm{YpH}$ & 6.13 & 6.14 & 6.3 & 6.02 & 5.94 & 0.564 & 5.78 \\
\hline $\mathrm{ApH}$ & 8.27 & 8.15 & 8.3 & 8.33 & 8.25 & 0.721 & 2.49 \\
\hline SG & 1.084 & 1.092 & 1.09 & 1.089 & 1.077 & 0.822 & 2.02 \\
\hline SR & 5.411 & 5.197 & 5.192 & 5.841 & 5.562 & 0.233 & 8.97 \\
\hline \multicolumn{8}{|c|}{ 2o cycle of production } \\
\hline HU & 92.29 & 93.15 & 88.62 & 92.68 & 91.27 & 0.081 & 2.77 \\
\hline $\mathrm{YI}$ & 0.49 & 0.50 & 0.47 & 0.51 & 0.53 & 0.080 & 6.36 \\
\hline Range & $6.10 \mathrm{~B}$ & $6.70 \mathrm{AB}$ & $7.70 \mathrm{~A}$ & $7.60 \mathrm{~A}$ & $6.90 \mathrm{AB}$ & $0.001^{*}$ & 7.95 \\
\hline L & $57.45 \mathrm{~B}$ & $59.51 \mathrm{AB}$ & $59.89 \mathrm{AB}$ & $58.42 \mathrm{AB}$ & $60.91 \mathrm{~A}$ & $0.032^{*}$ & 2.79 \\
\hline$a^{*}$ & -4.63 & -4.89 & -5.04 & -5.22 & -5.15 & 0.595 & 12.69 \\
\hline$b^{*}$ & 45.69 & 45.74 & 47.83 & 44.16 & 48.06 & 0.328 & 7.11 \\
\hline YP & 25.58 & 24.94 & 26.54 & 26.64 & 26.24 & 0.267 & 5.17 \\
\hline SP & 9.68 & 9.54 & 9.61 & 9.87 & 9.83 & 0.679 & 4.26 \\
\hline PA & 64.74 & 65.43 & 63.84 & 63.48 & 63.92 & 0.168 & 2.01 \\
\hline ST & 0.37 & 0.4 & 0.38 & 0.41 & 0.4 & 0.331 & 8.43 \\
\hline $\mathrm{YpH}$ & 5.99 & 5.91 & 5.92 & 5.92 & 5.98 & 0.311 & 1.44 \\
\hline $\mathrm{A} \mathrm{pH}$ & $8.13 \mathrm{~B}$ & $8.31 \mathrm{AB}$ & $8.42 \mathrm{~A}$ & $8.23 \mathrm{~B}$ & $8.50 \mathrm{~A}$ & $<0.001^{\star}$ & 1.97 \\
\hline SG & 1.089 & 1.087 & 1.087 & 1.085 & 1.09 & 0.252 & 0.31 \\
\hline $\mathrm{SR}$ & 4.871 & 4.974 & 5.399 & 5.298 & 5.283 & 0.544 & 11.09 \\
\hline \multicolumn{8}{|c|}{ 3o cycle of production } \\
\hline $\mathrm{HU}$ & 97.41 & 91.10 & 85.35 & 95.14 & 94.45 & 0.374 & 7.07 \\
\hline $\mathrm{YI}$ & 0.48 & 0.47 & 0.45 & 0.48 & 0.47 & 0.092 & 4.06 \\
\hline Range & $6.70 \mathrm{~B}$ & $7.80 \mathrm{~A}$ & $8.00 \mathrm{~A}$ & $8.30 \mathrm{~A}$ & $8.50 \mathrm{~A}$ & $0.001^{*}$ & 7.41 \\
\hline $\mathrm{L}$ & 27.78 & 26.42 & 26.54 & 28.17 & 28.02 & 0.109 & 4.57 \\
\hline$a^{*}$ & $9.44 \mathrm{~A}$ & $8.84 \mathrm{AB}$ & $8.66 \mathrm{AB}$ & $8.40 \mathrm{AB}$ & $7.72 \mathrm{~B}$ & $0.012^{\star}$ & 7.46 \\
\hline$b^{*}$ & 62.76 & 64.73 & 64.80 & 63.42 & 64.25 & 0.122 & 2.12 \\
\hline YP & $0.38 \mathrm{~A}$ & $0.35 \mathrm{AB}$ & $0.34 \mathrm{AB}$ & $0.33 \mathrm{AB}$ & $0.28 \mathrm{~B}$ & $0.023^{*}$ & 8.88 \\
\hline SP & 6.13 & 5.98 & 6.00 & 6.06 & 6.10 & 0.757 & 5.98 \\
\hline PA & 7.99 & 7.99 & 8.02 & 8.15 & 8.28 & 0.211 & 2.62 \\
\hline ST & 1.084 & 1.082 & 1.115 & 1.077 & 1.086 & 0.456 & 2.07 \\
\hline Y pH & 4171 & 3955 & 3802 & 4015 & 3381 & 0.572 & 18.66 \\
\hline
\end{tabular}

Note: $\mathrm{CV}=$ Coefficient of variation; * $\mathrm{P}<0.05$ indicates the difference between treatments, the differences being shown by equal letters on the same line (Tukey test). 


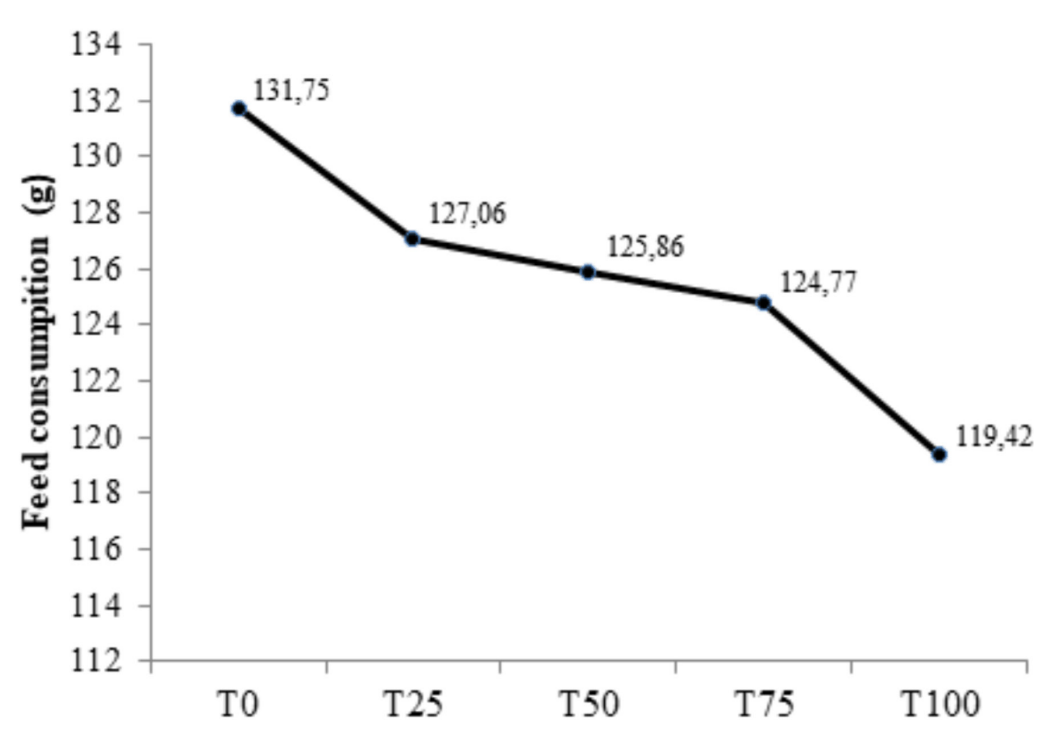

Figure 1. Feed consumption ( $\mathrm{g} /$ $\mathrm{bird} /$ day) of hens in the second cycle of production (days 29 to 56 of experiment).

Treatments
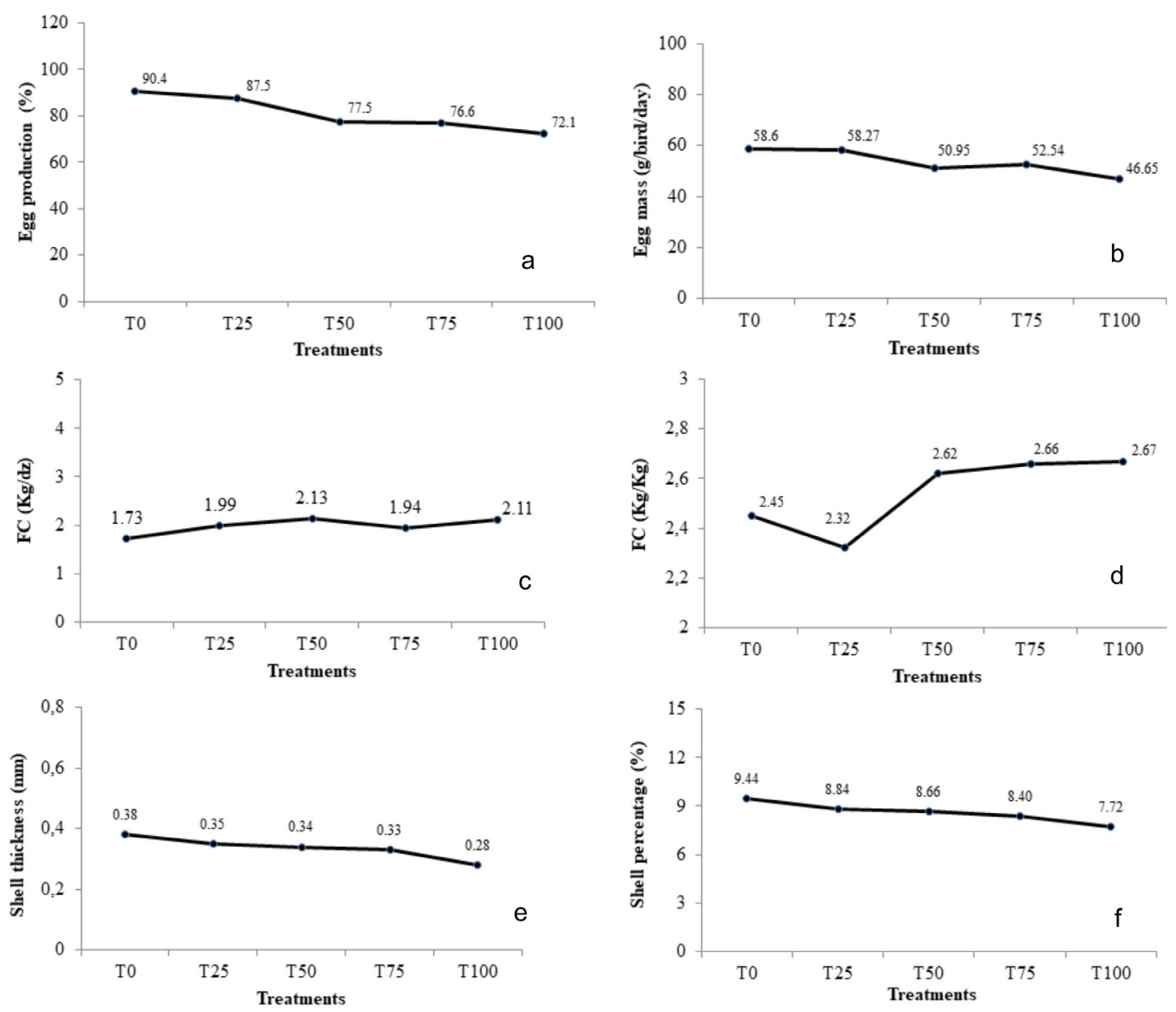

Figure 2. Eggs production (a); Egg mass (b); Feed conversion $\mathrm{kg} / \mathrm{dz}$ (c); Feed conversion $\mathrm{kg} / \mathrm{kg}$ (d); shell thickness (e) and egg shell percentage (f) third cycle of production (day 57 to 84 of experiment). 


\section{CONCLUSION}

The use of industrial egg residue cannot replace limestone in the feed of commercial laying hens, because it reduces performance and affects egg quality. The metabolizability of crude energy was lower with the inclusion of IER owing to the low digestibility of dry matter and crude protein, probably because of the high mineral concentration in the by-product. In the long run, the shell percentage and shell thickness of eggs decreased with higher IER levels, negatively affecting egg quality. IER in the diet also caused laying hens to break and ingest the eggs shortly after laying.

\section{Acknowledgments}

We thank the Fundação de Amparo à Pesquisa e Inovação do Estado de Santa Catarina (FAPESC), Coordenação de Aperfeiçoamento de Pessoal de Nivel Superior (CAPES) and Conselho Nacional de Desenvolvimento Científico e Tecnológico (CNPq) for technical support for authors.

\section{REFERENCES}

BRONNER F. 1998. Calciun absortion - a paradigm for mineral absortion. J Nutr 128(5): 917-920.

COSTA CHR, BARRETO SLT, UMIGI RT, LIMA HJD, ARAUJO MS \& MEDINA P. 2010. Balance of calcium and phosphorus and study of these minerals in diets for Japanese quails (from 45 to 57 weeks of age). Rev Bras Zootec 39(8): 1748-1755.

COSTA VA. 2009. Energy values and digestibility coefficients for birds determined in diets with nutritional corrections. Dissertation, Universidade Federal de Lavras, Brazil. (Unpublished).

CUPERTINO ES, GOMES PC, ROSTAGNO HS, DONZELE JL, SCHMIDT M \& MELLO HHC. 2009. Nutritional requirement of methionine+cistine digestibles for laying hens during a period of 54 to 70 weeks of age. Rev Bras Zootec 38(7): $1238-1246$.

FREITAS ER, SAKOMURA NK, GONZALEZ MM \& BARBOSA NAA. 2004. Comparison of methods to measure the specific gravity of laying hen eggs. Pesq Agrop Bras 39(5): 509-512.

GARCIA AAP. 2010. Prediction equations of energy values of animal meal for poultry, using the principle of meta-analysis. Dissertation, Universidade Federal de Lavras, Brazil.

HAUGH RR. 1937. The Haugh Unit for measuring egg quality. United States Egg Poultry Magazine 4: 552.

LOBAUGH B, JOSHUA IG \& MUZLLER WJ. 1981. Regulation of calcium appetite in broiler chickens. J Nutr 111(2): 298-306.

LEÃO APA. 2018. Digestibility and bioavailability of different sources of calcium for quail. Dissertation. Universidade Federal de Alagoas, Brazil. (Unpublished).

LIMA HFF. 2016. Productive performance and egg quality of laying hens fed different sources of calcium. Dissertation, Universidade Federal Rural do Semiárido, Brazil. (Unpublished).

MARINHO AL, LANA SRV, LANA GRQ, LIRA RC, CAMELO CL, VIANAJÚNIOR PC \& AMORIM PL. 2010. Effect of the inclusion of waste guava on the carcass yield of japanese quails (Coturnix coturnix japonica). Rev Cient Prod Anim 12(1): 46-49.

MATTERSON LD, POTTER LM, STUTZ MW \& SINGSEN EP. 1965. The metabolible energy of feed ingredients for chickens. 7 ed. Storrs Agricultural Experiment Station: United Kingdom.

MURAKAMI FS, RODRIGUES PO, CAMPOS CMT \& SILVA MAS. 2007. Physicochemical study of $\mathrm{CaCO}_{3}$ from egg hells. Ciênc Tecnol Alim 27(3): 658-662.

REIS RS, BARRETO SLT, LIMA HJD, PAULA E, MUNIZ JCL, MENCALHA R, VIANA GS \& BARBOSA LMR. 2012. Replacement of limestone by egg shell meal in the diet of Japanese quail from 40 to 52 weeks of age. Rev Bras Agrop Sust 2(2): 107-112.

ROSTAGNO HS, ALBINO LFT, DONZELE JL, GOMES PC, OLIVEIRA RF, LOPES DC, FERREIRA AS \& BARRETO SLT. 2017. Tabelas brasileiras para aves e suínos: composição de alimentos e exigências nutricionais. 4â ed., p. 327. Viçosa, MG: UFV, DZO.

SÁ LM, GOMES PC, ALBINO LFT, ROSTAGNO HS \& D'AGOSTINI P. 2004. Calcium requirement and bioavailability of some feedstuffs for broiler chicks from 1 to 21 days old. Rev Bras Zootec 33(1): 157-168.

SAKOMURA NK \& ROSTAGNO HS. 2007. Métodos de pesquisa em nutrição de monogástricos. Jaboticabal: Funep, 283 p.

SILVA DJ \& QUEIROZ AC. 2006. Análise de alimentos: métodos químicos e biológicos. 3ạ ed., Viçosa: UFV, 235 p.

VIEIRA MM. 2009. Calcium metabolism in broilers and posture with organic acids and phytase in the diet. $\mathrm{Ph}$. 
D. Thesis, Universidade Federal do Rio Grande do Sul, Brazil.

\section{How to cite}

BARRETA M, BOIAGO MM, ZAMPAR A, FORTUOSO BF, GEBERT RR, ROSCAMP E, OLIVEIRA RC, DALIANE JD, KOLM M, GALLI GM \& DA SILVA AS. 2021. Inclusion of industrial egg residue in the feed of laying hens to replace limestone: digestibility, productive performance and egg quality. An Acad Bras Cienc 93: e20190769. DOI 10.1590/0001-3765202120190769.

Manuscript received on July 10, 2019;

accepted for publication on January 21, 2020

\section{MAURICIO BARRETA}

https://orcid.org/0000-0001-6261-2182

\section{MARCEL M. BOIAGO ${ }^{1,2}$}

https://orcid.org/0000-0002-0950-4577

\author{
ALINE ZAMPAR ${ }^{1,2}$ \\ https://orcid.org/0000-0002-2269-7932

\section{BRUNO F. FORTUOSO 2} \\ https://orcid.org/0000-0001-6090-6590
}

ROGER R. GEBERT ${ }^{2}$

https://orcid.org/0000-0001-5581-8860

\section{EDUARDO ROSCAMP ${ }^{2}$}

https://orcid.org/0000-0002-4770-7578

ROSILENE C. OLIVEIRA ${ }^{2}$

https://orcid.org/0000-0003-1147-3076

JÉSSICA D. DALIANE ${ }^{2}$

https://orcid.org/0000-0002-2830-3930

\section{MARINDIA KOLM}

https://orcid.org/0000-0002-1246-4107

\section{GABRIELA M. GALLI ${ }^{1}$}

https://orcid.org/0000-0001-6734-8659

\begin{abstract}
ALEKSANDRO S. DA SILVA ${ }^{1,2}$
https://orcid.org/0000-0002-9860-1933

${ }^{1}$ Programa de Pós-Graduação em Zootecnia, Universidade do Estado de Santa Catarina (UDESC), Rua Beloni Trombeta Zanin, 680 E, Santo Antônio, 89815-630 Chapecó, SC, Brazil ${ }^{2}$ Departamento de Zootecnia, UDESC, Rua Beloni Trombeta Zanin, 680 E, Santo Antônio, 89815-630 Chapecó, SC, Brazil ${ }^{3}$ Cooperativa Central Aurora Alimentos, Rua João Martins, 219 D, São Cristóvão, 89803-040 Chapecó, SC, Brazil
\end{abstract}

Correspondence to: Marcel M. Boiago, Aleksandro S. da Silva

E-mails:mmboiago@gmail.com; aleksandro_ss@yahoo.com.br

\section{Author contributions}

Mauricio Barreta: Master's student in Animal Science, responsible for preparing and executing the project and writing the manuscript. Marcel M. Boiago and Aleksandro S. da Silva: Professors. Responsible for writing the project, monitoring, supervising and guiding the students. Aline Zampar: Responsible for designing and performing statistical analysis of the experiment, in addition to assisting in the discussions of the results. Bruno F. Fortuoso and Roger R. Gebert: They helped with blood collections, performed blood calcium analysis and contributed to writing the manuscript. Eduardo Roscamp, Rosilene C. Oliveira and Jéssica D. Daliane: Scientific initiation students. They helped in the implementation and conduction of the experiment I (digestibility assay), in addition to helping to calculate digestibility values. Marindia Kolm and Gabriela M. Galli: They helped to prepare the rations and with the daily handling of the birds of the experiment II. They also performed the egg quality analysis.

\section{(cc) BY}

